\title{
JUDICIAL CORPORAL PUNISHMENT IN THE UNITED STATES? LESSONS FROM ISLAMIC CRIMINAL LAW FOR CURING THE ILLS OF MASS INCARCERATION
}

Mohamed A. Arafa* and Jonathan G. Burns**

\begin{abstract}
"God makes some hearts so soft that they are softer than milk, and He makes others even harder than stones."1

"Prison is a mystery to all but the millions of people forced to live and work in this gigantic government-run detention system. And as long as we don't look at what happens on the inside, as long as we refuse to consider alternatives, nothing will change." 2
\end{abstract}

\section{PART I: INTRODUCTION}

At year-end 2012, approximately 2,312,300 individuals were incarcerated in United States jails and prisons nationwide. ${ }^{3}$ To visualize this, consider almost all of Chicago, half of Ireland, or the whole of Jamaica bounded on all sides by prison walls. This number, however large, represents only adult individuals who are in physical custody; it does not include juveniles and those adults who are in the system, but not in prison or jail. The entire adult correctional population (consisting of individuals on probation, parole, or in prison or jail) consists of 6.94 million people, equivalent to about

\footnotetext{
* Assistant Professor of Criminal Law and Criminal Justice, Alexandria University Faculty of Law (Egypt); Adjunct Professor of Islamic Law, Indiana University Robert H. McKinney School of Law (United States). S.J.D., Indiana University Robert H. McKinney School of Law (2013); LL.M., University of Connecticut School of Law (2008); LL.B., Alexandria University School of Law (2006). Professor 'Arafa is a Visiting Professor of Business Law at the Arab Academy for Science, Technology, and Maritime Transport. Moreover, Professor 'Arafa served as an Associate Attorney and Executive Attorney Assistant at 'Arafa Law Firm (2007). For comments or questions please contact the author at marafa@iupui.edu or arafadr_mohamed@yahoo.com.

** J.D., Indiana University Robert H. McKinney School of Law (2014); B.A., Evangel University (2010). Mr. Burns is an Associate at the international law firm Dentons in Riyadh, Kingdom of Saudi Arabia, and is the author of INTRODUCTION TO Islamic LAW: PrinCIPLES OF CiVIL, CRIMINAL, AND INTERNATIONAL LAW UNDER THE SHARI’A (2013). The authors wish to thank Ahmad ElAshry for his kind assistance in conducting research for this Article.

${ }^{1}$ Adil Salahi, MuHAmmad: MAN AND PROPHET 259 (1995).

2 Peter Moskos, In Defense of Flogging 5 (2011).

${ }^{3}$ Press Release, Bureau of Justice Statistics, Total U.S. Correctional Population Declined in 2012 for Fourth Year (Dec. 19, 2013), http://perma.cc/FR49-X55S.
} 
1 in 35 U.S. adults or 2.9 percent of the entire adult population in the United States. ${ }^{4}$ Unsurprisingly, these numbers represent the highest incarceration rate in the world. ${ }^{5}$ At 716 incarcerated individuals per 100,000 citizens, our total population of prisoners eclipses all others-including China, Russia, and Cuba. ${ }^{6}$

To put it mildly, the cost of housing, feeding, clothing, supervising, providing medical care for, and otherwise maintaining these individuals is not cheap. At the federal level, annual prison budgets have recently exceeded $\$ 6.5$ billion; and the annual cost-per-inmate ranges from $\$ 21,006$ for minimum-security offenders to $\$ 33,930$ for high security offenders. ${ }^{7}$ At the state level, annual spending on corrections by the individual states stands near $\$ 52$ billion in total, the bulk of which goes to expenditures for state prisons. ${ }^{8}$ And to further compound the problem, individuals who have entered the incarceration system, served their time, and been released have essentially a coin flip's chance of entering the system again. ${ }^{9}$

\section{A. Issue}

From these facts, it is evident that the U.S. system of incarceration is both expensive (due to the large state and federal expenditures required) and lacking in efficacy (due to high probabilities of reincarceration). While this system of incarceration is dismal in the economic sense, it is also socially and emotionally depressing. While the punishment of imprisonment acts to protect society by separating potentially dangerous individuals from the outside world, it also breaks apart families, removes employees from their jobs, and disconnects young people from potentially the only positive role models they will encounter in their childhood. Is judicial corporal punishment in lieu of incarceration a better option?

\footnotetext{
${ }^{4}$ Id.

${ }^{5}$ Roy Walmsley, InT’L Ctr. Prison StUdies, World Prison PopUlation List 1 (10th ed. 2013), available at http://perma.cc/AD8V-MFS5.

${ }^{7}$ Nancy La Vigne \& Julie Samuels, The Growth \& Increasing Cost of the Federal Prison SYSTEM: DRIVERS AND POTENTIAL SOLUTIONS 2 (2012), available at http://perma.cc/9QQ6-UCC9. 8 PeW Ctr. On the States, State of Recidivism: The ReVolving DoOr OF America's Prisons 1 (2011), available at http://perma.cc/B4LE-FMFT.

${ }^{9}$ A study conducted by the Bureau of Justice Statistics, which tracked 272,111 inmates in fifteen states for three years after their release in 1994, found that 67.5 percent of the individuals were rearrested and 51.8 percent of the individuals ended up back in prison. PATRICK A. LANGAN \& DAVID J. LEVIN, RECIDIVISM OF PRISONERS RELEASED IN 1994, at 1, (2002), available at http://perma.cc/PFY5-DQL4. A study conducted by the Pew Center on the States, in collaboration with the Association of State Correctional Administrators, largely corroborated these statistics. Specifically, the Pew study tracked inmates released from prisons in every State in 1999 and 2004. Pew CTR. ON THE StAtes, supra note 10, at 2. After three years of release, Pew found that 45.4 percent of the individuals released in 1999 and 43.3 percent of those released in 2004 had been reincarcerated. $I d$.
} 
B. Scope

Several possible solutions exist for curing the problems of criminality, recidivism, and mass incarceration; judicial corporal punishment alone is not necessarily the principal answer. ${ }^{10}$ However, the implementation of judicial corporal punishment, to a certain degree, is superior to the status quo of incarceration in the United States. The purpose of this Article, therefore, is to analyze this claim that judicial corporal punishment represents a more effective, less costly, and more humane alternative to incarceration. In evaluating this assertion, the Article focuses on the example of judicial corporal punishment as implemented in jurisdictions applying Islamic criminal law.

The scope of analysis here is limited to policy, not practice. That is, the methods by which judicial corporal punishment are carried out are not intricately probed, except where necessary. Moreover, a full-scale recommendation for overhauling the criminal code and/or sentencing guidelines of a given jurisdiction by implementing judicial corporal punishment is beyond this Article's scope. Rather, the study seeks to provide taxpayers and policymakers with information about the objective policy behind judicial corporal punishment and how it could help significantly reduce the huge economic and social costs which incarceration levies on American society.

Accordingly, Part II examines the five universal purposes of punishment and offers a working definition of judicial corporal punishment. This follows with a comparative analysis of judicial corporal punishment under the U.S. and Islamic legal systems. Here, the authors conclude that, while judicial corporal punishment has de facto been eliminated in the United States, it is not necessarily forbidden under the Eighth Amendment of the U.S. Constitution. Part III, in turn, examines the drawbacks of judicial corporal punishment as implemented under Islamic criminal law. The authors here suggest that, despite its limitations, judicial corporal punishment as implemented in Islamic criminal law is more effective, less costly, and more compassionate than the status quo of incarceration. Finally, Part IV concludes by discussing some practical aspects to consider in light of the somewhat shocking issues confronted in this Article.

No rational person enjoys the thought of inflicting corporal punishment on anyone; the very thought seems repugnant, backward, barbaric, and brutal. However, so long as mass incarceration results in broken families, a diminished workforce, and ever-increasing taxpayer burdens, American

\footnotetext{
${ }^{10}$ Including, for example, decriminalizing certain non-violent and victimless offenses, advancing legislation aimed at expunging criminal records and ending discrimination against former inmates, or even pouring more money into the prison system to offer more rehabilitative programs or to improve the programs already available.
} 
society as a whole will suffer under a system that is repugnant on a much broader scale.

\section{PART II: BACKGROUND}

\section{A. The Five Universal Purposes of Punishment}

In a broad sense, there are five different criminal punishment policies which apply universally among all societies and legal systems; ${ }^{11}$ these include (1) incapacitation, (2) deterrence, (3) rehabilitation, (4) restitution, and (5) retribution. ${ }^{12}$ The policy of any given jurisdiction may be inspired by more than one theory of punishment.

Incapacitation refers to the technique of rendering a criminal powerless to commit further crime. ${ }^{13}$ This can be achieved, for example, by incarceration, amputation, or execution. Deterrence refers to the goal of discouraging both the criminal and other individuals in society from committing criminal acts. ${ }^{14}$ Deterrence can be achieved by public flogging, incarceration, monetary fines, and other means. Rehabilitation refers to the process by which attempts are made to help former criminals reenter society as productive citizens. ${ }^{15}$ This can be achieved, for example, by ordering offenders to undergo counseling, engage in community service, or attend job training classes. The theories of restitution and retribution are somewhat interrelated. However, the former is aimed at making the victim whole at the expense of the criminal in a material, property-based sense, while the latter is aimed at satisfying a purely emotional desire to exact vengeance on a wrongdoer. ${ }^{16}$ Restitution can be achieved, for example, by ordering a thief to return stolen property to the victim or ordering a vandal to pay for the repair of her victim's damaged property. Retribution, on the other hand, which seeks to inflict harm on the criminal for damages caused to her victim, ${ }^{17}$ can be achieved by physical punishments such as flogging. Each of these policies, to one degree or another, enjoy support in both U.S. and Islamic criminal legal systems. Specifically, the policies of incapacitation, deterrence, and rehabilitation are common influences of both systems.

${ }^{11}$ Cyndi BanKs, CRiminal Justice ETHICs 130 (3d ed. 2013).

${ }^{12}$ Id. at 114; see also, Kenneth R. Feinberg, The Federal Guidelines and the Underlying Purposes of Sentencing, 10 FED. SENT'G REP. 39, 39 (1997); Albert W. Alschuler, The Changing Purposes of Criminal Punishment: A Retrospective on the Past Century and Some Thoughts about the Next, 70 U. CHI. L. Rev. 1, n.1 (2003); John B. Mitchell, Crimes of Misery and Theories of Punishment, 15 NEW CRIM. L. REV. 465, 471, n.4 (2012).

${ }^{13}$ BANKs, supra note 13, at 127.

${ }^{14} \mathrm{Id}$. at 117.

${ }^{15}$ Id. at 125.

${ }^{16}$ Id. at $120-29$.

${ }^{17}$ Id. at 120. 


\section{B. What Is Judicial Corporal Punishment?}

The term "corporal punishment" is subject to widely varying definitions based on many subjective factors, including cultural norms and values, personal experience, education, religious affiliation, social status, and so on. Definitions can be broad ${ }^{18}$ or narrow. ${ }^{19}$ For purposes of this Article, "corporal punishment" refers to an affirmative act of physical harm not including death, a serious risk of death, or organ failure. The term "judicial" qualifies the act of punishment as one duly ordered by a court or judge after the opportunity of a fair trial and proof of guilt beyond a reasonable doubt. As a judicial act, the presumption here is that the punishment complies with all relevant constitutional provisions and rights including, inter alia, equal protection of the law, the right against self-incrimination, the right to confront and cross-examine witnesses, and due process of law (both substantive and procedural). In other words, the concept of applying judicial corporal punishment in the United States is contingent upon the highest level of fundamental fairness in all stages of the criminal process.

\section{A Comparative Analysis: Criminal Punishment in the Islamic and U.S. Legal Systems}

Many scholars and students with an Islamic legal background often lack a basic understanding of fundamental U.S. legal principles and structures. Their Western counterparts similarly lack a basic understanding of Islamic law, its sources, rules, and underlying policy rationales. While an in-depth discussion of either legal system's foundational principles falls outside the scope of this Article, ${ }^{20}$ the following brief introduction addresses their respective methods of punishment, the reasons for implementation (or lack of implementation), and the underlying policy aspirations. This section begins with an analysis of the methods and policy of criminal punishment under Islamic criminal law. It follows with an overview of U.S. jurisprudential history and attitudes toward criminal punishment and concludes with an analysis of U.S. policy on incarceration.

\footnotetext{
18 See, e.g., Black's LaW Dictionary 1353 (10th ed. 2014) (defining corporal punishment as "physical punishment; punishment that is inflicted upon the body (including imprisonment)"); and Geoffrey Scarre, Corporal Punishment, 6 Ethical TheORY \& Moral PraC. 296, 297, n.3 (2003) ("[I]n the broad sense, any punishment inflicted on the body meant to cause physical pain, discomfort or injury counts as 'corporal.'”).

${ }^{19}$ See, e.g., Scarre, supra note 20, at 1269 ("[F]or the term [corporal punishment] to apply in the narrow sense, the pain or harm must be intentionally produced by an act of battery or assault.”).

${ }^{20}$ For a thorough introduction to the basics of Islamic law in general, see JONATHAN G. BURNS, INTRODUCTION TO ISLAMIC LAW: PRINCIPLES OF CIVIL, CRIMINAL, AND INTERNATIONAL LAW UNDER THE SHARI'A 109-29 (2014), which includes a chapter covering all aspects of Islamic criminal law. See also, RAJ BHALA, UnDERSTANDING IsLAMIC LAW (SHARI’A) (2011).
} 
1. Overview of Punishment in Islamic Criminal Law - Methods and Policy

\section{a. Analysis of Crime and Punishment in Islamic Criminal Law}

Islamic law criminalizes certain behavior within three different categories. These categories consist of Hudud, Quesas, and Ta'azir offenses. Thus, this section will outline these categories of crime under Islamic criminal law, their punishments, and their evidentiary requirements.

\section{HUDUD OFFENSES}

Hudud (the plural of "Hadd") are offenses sanctioned by fixed legal penalties. ${ }^{21} \mathrm{Hudud}$ crimes are those that bring harm to the essential interests of an Islamic community; they imply a grave aggression on society's peace, order, and virtue. ${ }^{22}$ Thus, punishment for Hudud crimes is the most strict and decisive in Islamic criminal law. Accordingly, specific Hudud offenses, their punishment, and mitigating and aggravating circumstances were fixed and detailed in provisions of the Qur'an ${ }^{23}$ and Sunnah. ${ }^{24}$ Considering the severity of Hudud penalties, Islamic Law requires the offender to be of capacity, acting of his own free will, and most importantly to be proven guilty of the crime beyond a reasonable doubt after a fair trial. It should be noted that "doubt" is of crucial importance in the application of Hudud penalties as will be shown later.

Hudud generally consist of four agreed-upon offenses: (1) Al-Zena, (2) Al-Qazf, (3) Al-Sariqah, and (4) Al-Haraba. ${ }^{25}$ The first of these offenses, Al-

${ }^{21}$ Taylor Kamel, The Principle of Legality and its Application in Islamic Criminal Justice, in THE IsLAmic CRIMINAL JuSTICE SYSTEM 149, 163-64 (M. Cherif Bassiouni ed., 1982) (citing AL-MAWARDI, AL-AHKAM AL-SULTANIYYA 219). See also generally Mohamed S. EL-'Awa, Punishment in Islamic Law-A Comparative Study (2000).

${ }^{22}$ See generally Muhammad Abu Zahrah, Crime and Punishment in Islamic JuRisprudence (1974).

${ }^{23}$ The Qur'an, the holy book of Muslims, is the first and the main source of Islamic law in which the word of God was revealed to the Prophet Muhammad (PBUH) verbally through the Angel Gabriel over a period of twenty-two years (610-632 C.E.). M. Cherif Bassiouni \& Gamal Badr, The Shari'ah: Sources, Interpretation, and Rule-Making, 1 UCLA J. ISLAMIC \& NEAR E.L. 135, 150 (2002).

24 The second principal source of Islamic Law is the Sunnah, or the traditions of Prophet Muhammad (PBUH). The Sunnah is important for the interpretation of Qur'anic verses. Id. See generally Nasser Ali Al-Kholaify, Mitigating and Aggravating Circumstances for PENALTY OF TA‘AZIR IN ISLAMIC JURISPRUDENCE (1992).

25 AL-KHOLAIFY, supra note 26, at 21. There are three other controversial offenses which are not discussed here; these include Shorb Al-Khamr, or drinking wine; Al-Baghi, or rebellion against legitimate authority; and Al-Ridda, or apostasy. Etim O. Okon, Hudud Punishments in Islamic 
Zena, relates to fornication or adultery. The crime may be proven by confession or the testimony of four eyewitnesses and is sanctioned by flogging with a hundred lashes. ${ }^{26} \mathrm{Al}$-Qazf, meaning to slander or defame an innocent person of the crime of fornication, is punishable by flogging with eighty lashes. The penalty requires the accused fornicator to demand the application of the penalty to the alleged perjurer. ${ }^{27} \mathrm{Al}$-Sariqah, or theft, is sanctioned by amputation of the hand. For the penalty to apply, the owner must claim his property and the stolen object must have been of a specific minimum value (which renders the offense grand theft and, thus, punishable as a Hudud offense, whereas petty theft is sanctioned by Ta'azir, as discussed in Part II.C.1.a.iii); completely owned and possessed by the owner at the time of its theft; and taken from the usual place of preservation (for example, a car in a garage or jewels in a vault). ${ }^{28}$ Additionally, the act of stealing must be a violation or an aggression inflicted on secure citizens in their secure places (i.e., it must be committed by stealth or by way of concealment). ${ }^{29}$ Finally, the act may only be proven by confession or by testimony of two eyewitnesses. ${ }^{30}$ Al-Haraba, meaning brigandage or spreading chaos, involves threats or acts of violence toward passers-by on public roads, which may or may not involve murder or larceny. ${ }^{31}$ It implies any act of aggression terrorizing secure citizens (associated with murder and theft or not) including acts of terrorism. ${ }^{32}$ The offense is punishable by various severe penalties, including death, crucifixion, amputation of the opposing limbs, or banishment. ${ }^{33}$ To be condemned for this crime, the offender must have used a weapon and acted without consideration of law or the safety of others. ${ }^{34}$

\section{QUESAS OFFENSES}

Quesas, meaning "equality" or "equivalence," refers to an offense punishable by the same or a substantially similar act in retaliation for the injury inflicted. ${ }^{35}$ In other words, Quesas involves the redress of a wrong by equalizing the harm. In certain cases, a victim or his legal representatives may demand other forms of compensation in lieu of physical punishment

Criminal Law, 10 EUR. SCI. J., no. 14, May 2014, at 227, 229, available at http://perma.cc/X3X2EU22.

${ }^{26}$ AL-KHOLAIFY, supra note 26, at 24.

${ }^{27}$ Id. at 27.

${ }^{28}$ ABU ZAHRAH, supra note 24, at 125.

${ }^{29}$ Id. at 122.

${ }^{30}$ AL-KHOLAIFY, supra note 26, at 32.

${ }^{31} \mathrm{Id}$. at 35.

${ }^{32}$ ABU ZAHRAH, supra note 24, at 143.

33 Id. at 146.

${ }^{34}$ AL-KhOLAIFY supra note 26, at 35.

${ }^{35}$ M. Cherif Bassiouni, Quesas Crimes, in The Islamic Criminal Justice SysteM, supra note 23, at 203, 203. 
(Diyya). ${ }^{36}$ As a third alternative, the victim or his legal representatives may wholly forgive the offender. ${ }^{37}$

Quesas offenses are divided into two categories. The first comprises the intentional act of murder (homicide). ${ }^{38}$ The second category involves the intentional infliction of bodily harm resulting in permanent or serious injury. ${ }^{39}$ This includes maiming, beating, wounding, and other forms of physical disfigurement. It should be noted that the formulation of a Quesas punishment is based on providing a well-balanced application of justice and equality.

These crimes involve an aggression on the most important personal rights. Those are the right to life and the right to corporal integrity. Note that punishment for Quesas crimes cannot be applied when the offender is related to the victim as, for example, if the offender is the son of the victim. ${ }^{40}$

Finally, note that an offender found guilty of causing unintentional murder or bodily injury is also liable for Diyya, but not subject to physical punishment by Quesas. ${ }^{41}$

\section{TA'AZIR OFFENSES}

Ta'azir means discipline, rehabilitation, or discretionary correction. It encompasses all offenses for which Shari'a does not prescribe a punishment. ${ }^{42}$ Thus, all acts (not included in Hudud, Quesas, or Diyya) infringing private interests of individuals or public interests of the community are included in the Ta'azir category. ${ }^{43}$ This imposes a duty on public authorities to codify rules penalizing such acts. At the same time, such wide discretion provides the flexibility necessary for the law to comply with the changes and developments in technology, culture, and the like of each new era. ${ }^{44}$

Examples given in the Qur'an for this category indicate that the judge has wide discretion in imposing punishments. ${ }^{45}$ However, the judge must consider the totality of the circumstances so as to render a penalty

\footnotetext{
${ }^{36}$ AL-KhOLAIFY, supra note 26, at 49.

37 "But if one is granted any remission by one's brother, then pursuing the matter for the realization of the blood money shall be done with fairness and the murderer shall pay him the blood money in a handsome manner.” QUR’AN, Al-Baqarah 2:179, available at http://perma.cc/429F-3VQJ.

38 "O ye who believe! equitable retaliation in the matter of the slain is prescribed for you." Id.

39 "And therein We prescribed for them: A life for a life, and an eye for an eye, and a nose for a nose, and an ear for an ear, and a tooth for a tooth, and for other injuries equitable retaliation.” Id. at Al-mäidah, 5:46, available at http://perma.cc/5ZN7-RLRM.

${ }^{40}$ AL-KHOLAIFY, supra note 26, at 53.

${ }^{41} \mathrm{Id}$. at 57.

42 Id. at $77-79$.

${ }^{43} \mathrm{Id}$. at 89.

${ }^{44} \mathrm{Id}$. at 97.

${ }^{45} \mathrm{Id}$. at 81 .
} 
proportionate to the crime (which must always be more lenient than those in $H u d u d) .{ }^{46}$ Such wide judicial discretion may include a pardon where the crime touches a personal right more than a public interest.

Ta'azir offenses include three classes of crime. The first class comprises crimes related to Hudud offenses, yet not so grave as to justify the prescribed Hudud punishment. The second class comprises Hudud offenses where the penalty is not applicable either because of the offender's condition (e.g., reduced mental capacity, lack of volition, or the like); or failure to satisfy the strict evidentiary requirements to prove a Hudud evidence, even though minimal evidence exists (e.g., where only three males witnessed an act of adultery, instead of the requisite four witnesses). In this case, the more severe Hadd penalty is replaced with the less severe Ta'azir penalty. The third class involves all other criminal acts that are not penalized with fixed legal punishment. ${ }^{47}$

Ta'azir penalties include traditional physical (corporal) punishment such as the death penalty, which is rarely imposed, and flogging. Deprivation of liberty is another penalty, which includes imprisonment, local banishment, displacement, or expulsion. Moreover, pecuniary penalties under Ta'azir include fines and seizure. In certain cases, judges may employ social control mechanisms — such as admonition or exhortation, reprimand, threat, or public disclosure - to deter offenders from repeating their evil acts. ${ }^{48}$

\section{INCARCERATION IN ISLAMIC CRIMINAL LAW}

Finally, it is important to note that incarceration, while disfavored in Islamic criminal law, is available as a means of dealing with offenders. Imprisonment existed long before Islam. ${ }^{49}$ However, neither the Qur'an nor the Sunnah provided for the penalty. When Islamic jurisprudence scholars provided for imprisonment in their legal commentaries, it typically applied only to minor Ta'azir offenses and for a period not exceeding one year. ${ }^{50}$ However, according to other various Islamic interpretations in Islamic fiqh (jurisprudence), incarceration in Islamic criminal law is mainly reserved for the most dangerous offenders and extreme recidivists. ${ }^{51}$ Such persons are not

\footnotetext{
46 See generally Bassiouni, supra note 37, at 233-234 (providing support that an important consideration in rendering judgments for criminal offenses is the proportionality between the crime and the punishment). Ta'azir offenses are similar to misdemeanors or minor felonies, whereas Hudud offenses are akin to major felonies.

${ }^{47}$ ABU ZAHRAH, supra note 24, at 89.

${ }^{48}$ See generally AL-KHOLAIFY, supra note 26, at 109-177.

49 "[I]f he do not what I bid him, he shall certainly be imprisoned and become one of the humbled." QUR’AN, Yūsuf 12:33, http://perma.cc/P4N4-MNGJ.

50 AL-KhOLAIFY, supra note 26, at 133.

51 Ahmad Abd al-Aziz al-Alfi, Punishment in Islamic Criminal Law, in The Islamic Criminal JuSTICE SYSTEM, supra note 23, at 227, 236.
} 
released from prison until the judge has determined that they have truly reformed and repented. ${ }^{52}$ Under Islamic law, incarceration is often considered more severe than corporal punishments, ${ }^{53}$ as punishment in Islamic criminal law must be determined according to the principles of equality and legality. ${ }^{54}$

\section{b. Philosophy of Punishment in Islamic Criminal Law}

The objective of Islamic law is to provide a flawless regulation for every aspect of human life ${ }^{55}$ to ensure the preservation of peace and order in the society. ${ }^{56}$ The public "interest" or "benefit" (Al-Maslahah) is the ultimate goal for regulations in Islamic law. ${ }^{57}$ Thus, the public interest is the basis of punishment in Islamic law. ${ }^{58}$ Under Islamic jurisprudence, the "public interest" comprises the "Five Essential Purposes," which include the protection of (1) religion, (2) life, (3) lineage, (4) intellect, and (5) property. ${ }^{59}$ As the Qur'an observes, "whoever kills a soul unless for a soul or for corruption [done] in the land - it is as if he had slain mankind entirely. And whoever saves one - it is as if he had saved mankind entirely."60 This verse clarifies that the infliction of a crime upon an individual is also an aggression on the community as a whole.

Accordingly, offenses that jeopardize the very foundation of society are strictly punished with fixed penalties (Hudud offenses). It was the catastrophic consequences they cause in community that was considered when fixing Hudud penalties. In particular, the spread of fornication and slander would lead to the disintegration of the family and corrupt the lineage in society. ${ }^{61}$ Additionally, the spread of theft would disrupt the peace and order of the society, leaving people with a sense of insecurity for their property or their life. ${ }^{6}$

Furthermore, punishment in Islamic law seeks to provide the perfect application of justice and equality. This is emphasized in the Qur'anic verse: "O believers, be you securers of justice, witnesses for God. Let not detestation for a people move you not to be equitable; be equitable-that is

\footnotetext{
${ }^{52}$ Ghaouti Benmelha, Ta'azir Crimes, in THE IsLAMIC CRIMINAL JuSTICE SYSTEM, supra note 23, at 211, 217.

${ }^{53}$ Bassiouni, supra note 37, at 228-230.

${ }^{54} \mathrm{Id}$.

${ }^{55} I d$. at 231.

${ }^{56} \mathrm{Id}$.

${ }^{57}$ Id. at 232, 233.

${ }^{58} \mathrm{Id}$.

${ }^{59} \mathrm{Id}$.

${ }^{60}$ QUR’AN, Sūrat l-māidah 5:32, available at http://perma.cc/VD6R-UQLV.

${ }^{61}$ Bassiouni, supra note 37, at 232, 233.

${ }^{62} I d$.
} 
nearer to godfearing . . . "63 In this regard, punishment for Quesas offenses seeks to provide the perfect manifestation of justice and equality. Punishment by Quesas is applied only in cases of deliberate aggression on the life or bodily integrity of the victim, which are personal rights applicable to every human being. Without punishment by Quesas, these acts of aggression could have created an endless circle of revenge that knew no equality where the strong preyed on the weak. Punishment by Quesas, as detailed, seeks to serve justice and equality by healing the victim or his relatives and friends. ${ }^{64}$

\section{c. Application of Punishment in Islamic criminal Law: Theory Versus Practice}

Evidence plays an important role in Islamic criminal law where the presumption of innocence is fundamentally protected. Since Hudud penalties are more severe that other sanctions, the following discussion is limited to these offenses. In this regard, evidentiary standards concerning witness testimony and confessions require some elaboration. ${ }^{65}$

First, evidence in support of conviction must be "conclusive" in order to "clearly and explicitly prove the occurrence of the criminal act without any need for explanation or interpretation." 66 The time, place, and all other circumstances of the alleged crime must be specified and, above all, must be consistent with all other evidence. Second, until the time of execution, the evidence must be conclusive. Third, there should be no delay in the presentation of evidence. If the means of obtaining evidence (from testimony or confession) does not fulfill these conditions, it raises doubt as to the authenticity of the allegation. And doubt, or Shobhah, according to the Prophetic Hadith, "precludes the application of Hudud penalties." 67

On the matter of testimony, Islamic jurists generally agree that for Hudud and Quesas offenses, two witnesses must provide consistent testimony. Witnesses must exhibit maturity, memory, speech, visual and audible awareness of the crime, moral integrity, authenticity where the witness must have seen and/or heard the incident himself, and, though subject to debate, acceptance of Islam. ${ }^{68}$ Testimony shall be disqualified because of blood relation, enmity, or partiality. Cases of adultery require the testimony of four male witnesses (though two female witnesses can substitute for one

${ }^{63}$ QUR’AN, Sürat l-māidah 5:8 available at http://perma.cc/K9V6-PH5W.

${ }^{64}$ Bassiouni, supra note 37, at 232, 233.

65 See Mohamed 'Arafa, Corruption and Bribery in Islamic Law: Are Islamic Ideals Being in Practice?, 18 ANN. SuRV. INT’L. \& CoMP. L. 171, 184-186 (2012).

${ }^{66}$ Ma'amoun M. Salama, General Principles of Criminal Evidence in Islamic Jurisprudence, in The Islamic CRIMINAL JUSTICE SySTEM, supra note 23, at 112.

${ }^{67} \mathrm{Id}$.

${ }^{68} \mathrm{Id}$. at 116. 
male witness) with consistent testimony provided at the same hearing. ${ }^{69}$

Confessions are inadmissible unless the confessor is of age, demonstrates maturity, and is capable of self-expression and acting of his own free will. The confession must be unequivocal, taking place in and during a legal hearing, and the judge must find it corroborated by other circumstances. ${ }^{70}$ A confession only implicates the accused and does not prove guilt unless the judge is fully convinced of it. ${ }^{71}$

Moving on to the Prophetic Hadith: "Doubt precludes the application

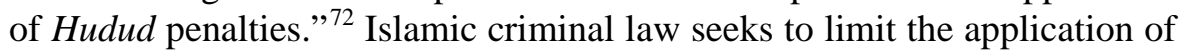
Hudud penalties to the greatest possible extent. Thus, Shobhah, or strong doubt, negates incrimination and results in a pardon of the accused, while weak doubt extenuates the penalty from Hudud to Ta'azir. ${ }^{73}$ Doubt can arise over a material element of the crime, the presence of criminal intent, the incrimination of controversial acts, or related evidence. ${ }^{74}$ For example, the Caliph 'Umar Ibn Al-Khattab refrained from imposing the punishment of amputation for an act of theft due to the circumstances of drought and starvation. ${ }^{75}$

Islamic criminal law further aspires to balance deterrence and incapacitation (through decisive penalties), with compassion and rehabilitation (by requiring strict conditions and allowing lenience). Another important issue is the mitigating and aggravating circumstances in Islamic criminal law. Both types of circumstances affect penalties differently in Hudud, Quesas, and Ta'azir offenses. For fixed punishment in Hudud and Quesas offenses alone, a penalty can never be aggravated or mitigated. However, the punishment could be aggravated or mitigated by adding or replacing a Ta'azir penalty in certain cases. ${ }^{76}$ As for unfixed punishments (Ta'azir), it is for the judge's discretion to consider the circumstances in light of the offense, including any mitigating circumstances, such as the offender's mental or physical status, age, family background, wealth, and the like. ${ }^{77}$ It is important to note that the general criterion for applying a more severe Ta'azir penalty is based on the effectiveness and deterrence of the punishment, while the previously mentioned Hadith provides for a less severe penalty where mitigating circumstances exist.

Aggravating circumstances include the danger imposed by the offender; the social class he represents (consideration of which serves to deter

\footnotetext{
${ }^{69} \mathrm{Id}$. at 118.

${ }^{70} \mathrm{Id}$. at $119-120$.

${ }^{71}$ Id. at 120.

${ }^{72} I d$.

${ }^{73}$ ABU ZAHRAH, supra note 24, at 224.

${ }^{74} \mathrm{Id}$. at $188-224$.

${ }^{75} \mathrm{Id}$. at 221.

${ }^{76}$ AL-KHOLAIFY, supra note 26, at 215-221.

${ }^{77} \mathrm{Id}$.
} 
the rich, rather than the poor); the effect he leaves on society (i.e., whether he is a factor in spreading crime); the potential for committing the offense in public; and the possibility of recidivism. The circumstances of the crime include the place and time of its commission, the gravity of the crime, and the status of the victim. ${ }^{78}$ Thus, whether aggravating or mitigating the punishment, the judge must balance the severity of the penalty with circumstances of the crime and the offender's status.

\section{d. The Policy of Judicial Corporal Punishment in Islamic Criminal Law}

As mentioned above, judicial corporal punishment under Islamic criminal law is required for certain hudud (fixed) offenses when strict evidentiary thresholds are met. Moreover, judicial corporal punishment, among other forms of punishment, is available at the discretion of the judge for tazir offenses.

The theories of penal policy supporting judicial corporal punishment in Islamic criminal law are equal to those supporting incarceration-namely incapacitation, deterrence, and rehabilitation. However, retribution may also play a role (for better or worse) in some cases in Islamic legal jurisdictions. This can occur when principles of criminal procedure and due process under Islamic law are violated when, for example, the judge deciding the case lacks disinterest or impartiality, and in cases where the court lacks competence and fairness.

The prescribed punishments of amputation arguably serve to incapacitate the criminal. Without the use of a hand, a thief is less likely to steal again. And without the use of opposing limbs, a criminal is likely unable to threaten, attack, and/or rob another individual again. Further, to the extent that flagellation renders the defendant non-ambulatory and confined to bed rest for recovery, this punishment also serves to incapacitate, albeit for a temporary period.

Amputation and flagellation serve the deterrence purpose of punishment by discouraging the criminal and society from committing crime. Individuals who undergo amputation for conviction of theft or highway robbery resulting in physical harm to the victim will be extremely discouraged from committing theft again, lest they lose remaining limbs. Further, these individuals are forever known in society as convicts, sinners, and reprobates due to the largely non-concealable nature of their punishment. Thus, society is deterred from committing the crime to avoid the visual stigma of amputation as a criminal punishment. In the same way, individuals subjected to the brutal and gruesome punishment of flagellation undergo excruciating pain both during and after the ordeal; and they bear their scars

${ }^{78}$ Id. 
forever. If carried out in public, society is reminded of the painful consequences that can result from commission of the specified Hudud offenses.

Finally, judicial corporal punishment under Islamic law serves a rehabilitative purpose in Islamic society. That is, according to the spirit and intent of Islamic criminal law, after a criminal has endured the physically excruciating and mentally shocking ordeal of judicial corporal punishment, she should immediately be turned over to the care and custody of her family. Thus, as the criminal recovers from her wounds and processes the mental and emotional shock of the punishment, she should constantly be in the presence of and attended to by her family-those who, ideally, care most for her functional and societal wellbeing. During this time, the family members and the criminal should convene, connect, and correct the problems in the criminal's life, thereby achieving the rehabilitative policy of criminal punishment.

\section{Overview of Criminal Punishment in the United States - From Judicial Corporal Punishment to Incarceration}

Western civilization has departed from the rest of the world in many respects. One such example is in the area of criminal punishment. There was a time when judicial corporal punishment was simply accepted as common sense. However, as Western civilization progressed, the implementation of judicial corporal punishment slowly came to be considered repugnant and, accordingly, was replaced with other forms of punishment-most prominently, incarceration.

\section{a. Historical and Constitutional Analysis of Judicial Corporal Punishment in the United States}

The following section provides an overview of approaches to judicial corporal punishment in the United States. Following a brief historical analysis of Anglo-American legal philosophy, this section examines the evolution of Eight Amendment jurisprudence and the death of judicial corporal punishment in the United States.

\section{a. English Ancestry}

American jurisprudence is derived in large part from the English Common Law tradition. Moreover, as Justice Antonin Scalia observed in 
Harmelin v. Michigan, ${ }^{79}$ several major provisions of the U.S. Bill of Rights, including the Eight Amendment, originate in the English Declaration of Rights of $1689 .{ }^{80}$ In determining the meaning and intent of the "cruell and unusuall Punishments [sic]" clause, Scalia cites the case of Titus Oates, an English clergyman whose perjury at the trials of 15 Catholics resulted in their executions. ${ }^{81}$ At the sentencing stage of Oates' trial for having committed the perjury, the judges exercised their discretion in implementing punishment intended to brutalize, humiliate, and ultimately kill Oates. Specifically, they ordered that he should stand in the stockade at specific times and places, be whipped by "the common hangman," and imprisoned for life. ${ }^{82}$ The Oates case helped prompt the English Declaration's “cruell and unusuall Punishments [sic]" clause. ${ }^{83}$ However, according to Scalia, it was the fact that the judges gave themselves extrajudicial discretion to inflict punishment on Oates, and not the sheer brutality of corporal punishments inflicted during that time, which gave rise to the clause ${ }^{84}$ In that regard, Scalia notes that "the vicious punishments for treason decreed in the Bloody Assizes (drawing and quartering, burning of women felons, beheading, disemboweling, etc.) were common in that period-indeed, they were specifically authorized by law and remained so for many years afterwards." ${ }^{\circ 5}$

\section{b. "Cruel and Unusual Punishment" in the Bill of Rights and in the Individual States}

In discussing the adoption of the Eighth Amendment to the U.S. Constitution, it is important to keep in mind the context of the debates over the Bill of Rights at the first Congress. At that time, the individual states were fiercely independent, protective of their individual sovereignty, and terrified of the adverse nature of a centralized, federal system of government, especially given the history of abuse back in England and in the colonies. ${ }^{86}$

\footnotetext{
79 See Harmelin v. Michigan, 501 U.S. 957, 994-95 (1991) (plurality opinion) (Kennedy, J., concurring in part and concurring in the judgment) (White, Marshall \& Stevens, JJ., dissenting).

${ }^{80} \mathrm{Id}$. at 966 (noting that "[t]here is no doubt that the [English] Declaration of Rights [of 1689] is the antecedent of our constitutional text. ... In fact, the entire text of the Eighth Amendment is taken almost verbatim from the English Declaration of Rights, which provided '[t]hat excessive Baile ought not to be required nor excessive Fines imposed nor cruell and unusuall Punishments inflicted'[sic]”); see also, Solem v. Helm, 463 U.S. 277, 285 (1983) (5-4 decision) (Burger, CJ., dissenting).

${ }^{81}$ Harmelin, 501 U.S. at 969-73.

${ }^{82}$ Id. at 970.

${ }^{83} \mathrm{Id}$. at 971 .

${ }^{84}$ Id.

${ }^{85}$ Id. at 968 (citing Anthony F. Granucci, “Nor Cruel and Unusual Punishments Inflicted:” The Original Meaning, 57 CALIF. L. REV. 839, 855-56 (1969)).

86 The Constitutional Convention: A Narrative History From the Notes of James MADISON 5 (Edward J. Larson \& Michael P. Winship, eds., 2005).
} 
Thus, members of Congress demanded a Bill of Rights that would restrain the federal government against foreseeable abuses carried out against the states and their citizens. ${ }^{87}$ Nonetheless, many states had similar provisions in their own constitutions proscribing "cruel or unusual punishments," ${ }^{88}$ or simply "cruel punishments." 89 It was Virginia's formula, influenced by the English Declaration, which was ultimately adopted as the text of the Eighth Amendment. $^{90}$

During this time, punishment under the criminal law was principally a matter of concern for the individual states and the federal government had a largely undeveloped role. ${ }^{91}$ Thus, the U.S. Supreme Court was not able to develop much precedent defining the constitutional limits of the Eighth Amendment. Moreover, judicial corporal punishment was widely accepted by the states and commonly implemented by state judicial authorities without question as to either its cruelty or unusualness. ${ }^{92}$

\section{c. Eighth Amendment Constitutional Jurisprudence}

It was not until 1890 that the Supreme Court hinted at the penal methods tolerated by the Eighth Amendment. In In re Kemmler, a convicted murderer filed a habeas corpus petition, alleging that New York's newlyenacted method of execution by electricity was a form of cruel and unusual punishment prohibited by the Eighth Amendment. ${ }^{93}$ First, the Court refused to incorporate the Eighth Amendment's protections against the states via the Fourteenth Amendment. ${ }^{94}$ In dicta, however, the Court went on to note that

${ }^{87}$ Id. at $149-150$.

88 See, e.g., Del. DeClaration of Rights $§ 16$ (1776); MD. DeClaration OF RightS art. XXII (1776); Mass. Declaration of Rights art. XXVI (1780); N.C. DeClaration OF Rights $\S X$ (1776); N.H. BILL OF RIGHTS art. XXXIII (1784).

${ }^{89}$ PA. CONST. art. IX, § 13 (1790); S.C. ConsT. art. IX, § 4 (1790).

90 See VA. DECLARATION OF RightS $§ 9$ (1776).

${ }^{91}$ Larson \& Winship, supra note 88, at 5.

92 Sanaz Alasti, Cruel and Unusual Punishment: Comparative Perspective in INTERNATIONAL CONVENTIONS, THE UNITED STATES AND IRAN 213 (2009) ("Most towns in New England boasted whipping posts and stocks near the commons or meetinghouse. As late as 1805, the penalty in Massachusetts for counterfeiting was the amputation of an ear after sitting in a pillory for an hour. The penalty for manslaughter consisted of having one's forehead branded in public, and many communities flogged perpetrators for petty theft.”)

${ }^{93}$ In re Kemmler, 136 U.S. 436 (1890).

94 The Incorporation Doctrine provides for the Constitutional Amendments in the Bill of Rights originally meant to constrain only the federal government - to be applied against and to restrain the several States. See GeOfFrey StONE ET AL., Constitutional LAW 729 (6th ed. 2009). Lexically, this is achieved through the Due Process Clause of the Fourteenth Amendment of the U.S. Constitution, which provides that no State shall deprive any citizen of due process of law. Id. Thus, Kemmler argued that the rights provided in the Eighth Amendment coincided with the definition of "due process" as provided in the Fourteenth Amendment and, therefore, that New York and other states could not inflict "cruel and unusual punishment” as contemplated in the Eighth Amendment 
the Constitution of New York contained language similar to its federal counterpart and that:

If the punishment prescribed for an offense against the laws of [New York] were manifestly cruel and unusual as burning at the stake, crucifixion, breaking on the wheel, or the like, it would be the duty of the [New York] courts to adjudge such penalties to be within the constitutional prohibition. ${ }^{95}$

The Court also hinted at the proposition that federal courts should be guided by the same rationale in regard to the Eighth Amendment. ${ }^{96}$ The Court went on to note that:

"Difficulty would attend the effort to define the exactness the extent of the constitutional provision which provides that cruel and unusual punishments shall not be inflicted; but it is safe to affirm that punishments of torture ... are forbidden by [the Eighth Amendment].” Punishments are cruel when they involve torture or a lingering death. ${ }^{97}$

For over seventy years following the decision in Kemmler, the Supreme Court's Eighth Amendment jurisprudence stagnated. The reason for this is largely due to the fact that the prosecution and punishment of crime has historically been a matter of state rather than federal concern. ${ }^{98}$ This changed in 1962, however, when the Court applied the Eighth Amendment to the states under the Doctrine of Incorporation. ${ }^{99}$ The Court's Eighth Amendment jurisprudence expanded further during the 1970s when the federal government took a significant role in crime control with the "War on

upon its citizens. However, this would have only been the first step in Kemmler's long battle. Even if Kemmler had successfully argued that the Eighth Amendment coincided with the definition of "due process" as provided in the Fourteenth Amendment, he would then have to persuade the Court that death by electrocution was a cruel and unusual punishment under the Eighth Amendment.

${ }^{95}$ In re Kemmler, 136 U.S. at 446.

${ }^{96} \mathrm{Id}$.

${ }^{97}$ Id. at 447 (quoting Wilkerson v. Utah, 99 U. S. 130, 135 (1878)). The definition of "torture” in 1890 likely referred to "extreme pain; anguish of body or mind; torment." WEBSTER's A DiCTIONARY OF THE ENGLISH LANGUAGE 442 (Acad. ed. 1874). An alternative definition was "a putting to the rack or severe pain to extort a confession or as a punishment; extreme pain; anguish of body or mind.” CHAMBER's ETYMOLOGICAL DiCTIONARY OF THE ENGLISH LANGUAGE 524 (Rev. ed. 1882).

${ }^{98}$ Kristin M. Finklea, Lisa M. Seghetti, Cong. Research Serv., RL32824, Federal Crime Control: Background, Legislation, ANd Issues 1 (2008) [hereinafter Federal CRime CONTROL], available at http://perma.cc/4796-4B2U.

${ }^{99}$ Robinson v. California, 370 U.S. 660 (1962) (White \& Clark, JJ., dissenting). 
Drugs." ${ }^{100}$ By this time, however, judicial corporal punishment had long since died in each individual State. ${ }^{101}$ Thus, the body of law under the Eighth Amendment today largely consists of questions of proportionality of punishment, ${ }^{102}$ extrajudicial corporal punishment, ${ }^{103}$ and corporal punishment in schools. ${ }^{104}$ There is no Supreme Court precedent that squarely addresses the constitutionality of judicial corporal punishment.

\section{d. Shifting Attitudes toward Judicial Corporal Punishment}

The gradual dying out of judicial corporal punishment in the United States is somewhat of a mystery; a mystery which is made more complex due to the nuanced nature of the U.S. system of law and government. That is, since the Eighth Amendment was not made applicable to the States until 1962 through the Incorporation Doctrine, and since the last incidence of judicial corporal punishment occurred ten years prior, ${ }^{105}$ there are potentially fifty different narratives about the use, struggle against, and eventual abolition of judicial corporal punishment, one narrative for each different State.

Alabama attorney and judicial corporal punishment advocate John Dewar Gleissner posits that judicial corporal punishment died out in the

\footnotetext{
100 The expansion of the federal government's role in crime control began to reach a peak in 1986, when Congress passed several pieces of legislation that made certain crimes a federal offense, crimes that had theretofore been under the sole jurisdiction of the States. FEDERAL Crime CONTROL, supra note 100 , at 2 .

101 The last incident of judicial corporal punishment occurred in the State of Delaware in 1952, when a 30 year-old man was punished with twenty lashes after being convicted of beating a 59 yearold woman. See Corporal Punishment, ENCYCLOPEADIA BRITANNICA, http://perma.cc/QQ8J-N28R (last visited Mar. 31, 2014); see also, “Only the Instrument of the Law”: Baltimore's Whipping Post, MD. Hist. Soc’Y (Oct. 3, 2013), http://perma.cc/2LGE-RLTM; see also, Jay Scriba, When the Whip Was Law, MiLwaUKeE J., March 3, 1964, at 16.

102 See, e.g., Weems v. United States, 217 U.S. 349 (1910) (finding that "punishment for crime should be graduated and proportioned to the offense," that a sentence of 15 years hard labor was disproportionate to the offense of falsification of a government document and was thus, cruel and unusual) (White, J., dissenting); see also, Ewing v. California, 538 U.S. 11 (2003) (finding that a sentence of 25 years to life imprisonment for a recidivist felon convicted of stealing 3 golf clubs was proportionate to the offense and, thus, not a cruel and unusual punishment) (Scalia \& Thomas, JJ., concurring in result) (Stevens \& Breyer, JJ., dissenting).

${ }^{103}$ See, e.g., Hudson v. McMillian, 503 U.S. 1 (1992) (finding that a prison guard's use of excessive physical force against a prisoner that caused minor injuries not requiring medical attention was cruel and unusual punishment) (Stevens, J., concurring in part and concurring in the judgment) (Blackmun, J., concurring in judgment) (Thomas, J., dissenting); see also Wilkins v. Gaddy, 559 U.S. 34 (2010) (finding that a prisoner's allegation that an unprovoked prison guard punched, kicked, kneed, and choked him was sufficient to state a § 1983 claim for relief for cruel and unusual punishment, even though the injuries were de minimis) (Thomas, J., concurring in judgment).

104 See, e.g., Ingraham v. Wright, 430 U.S. 651 (1977) (finding that disciplinary corporal punishment applied by a public school official on a student was not cruel and unusual punishment) (White \& Stevens, JJ., dissenting).

${ }^{105}$ See supra text accompanying note 101.
} 
United States as the level of equality, racial harmony, and social mobility amongst citizens increased. ${ }^{106}$ That is, as a historical fact, criminals in society are generally drawn from the lowest ranks of status and wealth. ${ }^{107}$ Throughout history, wealthier individuals generally avoided criminal punishment because they either never needed to commit a crime in the first place in order to secure basic necessities or, alternatively, they could simply bribe the judicial authorities for leniency. As a result, judicial corporal punishment was applied almost exclusively to the poor. ${ }^{108}$ Apart from wealth status, Gleissner notes, the improvement of race relations also played a role in the demise of judicial corporal punishment. ${ }^{109}$ That is, the brutal act of corporal punishment was undeniably reminiscent of the evil institution of slavery, which by the late-nineteenth century led Americans to demand that all forms of corporal punishment on adults be abolished. Thus, Gleissner notes, as equality, tolerance, acceptance, and social mobility amongst the lower ranks of society began to increase in the United States, the very thought of judicial corporal punishment became repugnant due to the lingering scars of slavery, racism, and oppression. ${ }^{110}$

Another view, however, posits that the demise of judicial corporal punishment began long before the anti-slavery movement in the United States gained momentum. This view points to the literature in the late eighteenth and early-nineteenth centuries, which largely condemned the practice of corporal punishment for its non-reformative attributes and celebrated imprisonment as a superior form of punishment and an opportunity to rehabilitate wayward fellow citizens. ${ }^{111}$ The noted reformist Horace Mann, as an example, "expressed widely shared sentiments when he declared that the fear of corporal punishment might 'make an offender cease to do ill,' but it can never 'make him love to do well.", 112

In any case, the fact is that judicial corporal punishment has been completely eradicated from the American penal philosophy and replaced with the current regime of fines, restitution, community service, suspended sentences and probation, miscellaneous alternative sentences, and

\footnotetext{
106 John Dewar Gleissner, Why Was Judicial Corporal Punishment Abolished?, INCARCERATION REFORM (Apr. 7, 2012), http://perma.cc/AD5U-8NZS.

${ }^{107} \mathrm{Id}$.

${ }^{108} \mathrm{Id}$.

${ }^{109} \mathrm{Id}$.

${ }^{110} \mathrm{Id}$.

111 Kevin J. Murtagh, Corporal Punishment: A Humane Alternative to Incarceration 2 (2012) ("Many reformers at the time had high hopes for the reformative potential of imprisonment and they were eager to leave behind a form of punishment that was thought to lack the ability to change the moral character of offenders.”); see also ALASTI, supra note 94, at 212, 213.

112 Myra Glenn, Campaigns Against Corporal Punishment: Prisoners, Sailors, Women, AND CHILDREN IN ANTEBELluM AMERICA 41 (1984).
} 
incarceration. ${ }^{113}$ This latter punishment, incarceration, will now be analyzed according to the five purposes of punishment.

\section{e. Criminal Punishment in the United States Today - The Objective Policy of Incarceration}

In a light most favorable to a proponent of incarceration, an examination of this method of punishment shows that it is heavily inspired by the incapacitation, deterrence, and rehabilitation theories of criminal punishment. First, incarceration serves to incapacitate otherwise harmful individuals in society by placing them in a controlled environment, extinguishing their ability to move freely throughout society, and subjecting them to constant surveillance and control. Thus, when a criminal is incarcerated, she is effectively rendered powerless in a criminal capacity.

Next, incarceration serves as a deterrent to both the criminal and society against the future commission of crime. That is, incarcerated criminals and individuals in society view incarceration as a severely unhappy and inconvenient experience. And, if these individuals view the risk of incarceration as outweighing the potential benefit of committing crime, then the punishment of incarceration has served its deterrent purpose.

Finally, incarceration serves a rehabilitative purpose for criminals in society. That is, when a criminal is incarcerated, she is generally away from the individuals and circumstances in society that may have encouraged or caused her to commit the criminal act(s). Thus, she is able to stop and reflect on her life, the choices she has made, and the path which she would like to take in the future. If this path does not involve any more crime, then incarceration has served its rehabilitative penal purpose. Incarceration as a form of punishment can become more rehabilitative when it includes additional benefits for the betterment of the criminal. For example, incarceration including access to counseling, job training, educational classes, and paid employment can help the criminal to become a better and more functional member of society when her time for release into the general public comes.

\section{PART III: ARGUMENT}

From the foregoing analysis in Part II, it is evident that incarceration and judicial corporal punishment as implemented in Islamic criminal law share the same penal aspirations. That is, the objective of both systems is incapacitation, deterrence, and rehabilitation. After considering the drawbacks of judicial corporal punishment as implemented in Islamic

113 Sentencing Alternatives: Prison, Probation, Fines, and Community Service, NoLO, http://perma.cc/93JX-8ZGN (last visited Mar. 31, 2014). 
criminal law, this section attempts to show how judicial corporal punishment is more humane, less costly, and more effective at meeting the common penal aspirations of rehabilitation and deterrence than incarceration by pointing to the longstanding example of its implementation in Islamic criminal law.

\section{A. Drawbacks of Replacing Incarceration with Judicial Corporal Punishment}

While this Article concludes that implementing judicial corporal punishment to some degree is superior to the status quo of incarceration in the United States, the drawbacks of judicial corporal punishment-in general and as specifically implemented in Islamic criminal law-must be exposed and confronted at the outset. Specifically, incarceration meets the incapacitation purpose of criminal punishment much more effectively than does judicial corporal punishment as implemented in Islamic criminal law. Further, in regard to situations where an innocent individual is wrongfully convicted and later exonerated, incarceration may be a superior form of punishment than judicial corporal punishment as implemented in Islamic criminal law. Finally, incarceration is superior to judicial corporal punishment as implemented in Islamic criminal law in regard to the treatment of certain individuals with unique mental and/or physical disabilities and individuals who simply pose an excessive risk of danger to society.

\section{Contradictoriness and Disadvantages of Amputation as a Form of Punishment in Islamic Criminal Law}

To begin, it must be acknowledged that the application of amputation as a criminal punishment in Islamic criminal law is largely inefficient, imprudent, and contradictory to the underlying policies which Islamic law in general seeks to support and develop. That is, if judicial corporal punishment in Islamic criminal law is purposed in, inter alia, reducing taxpayer burdens, rehabilitating the offender, and allowing him to continue to contribute to the wellbeing of society and his family, then amputation fails to achieve these goals since the amputee-offender is at risk of losing his ability to work and provide for his family, thereby increasing the chance that both he and his family will be driven to more crime and/or become taxpayer burdens. Thus, as a preliminary matter regarding the drawbacks of judicial corporal punishment as implemented in Islamic criminal law, it is appropriate to begin with an acknowledgement that the adverse consequences of amputation substantially outweigh its positive effects of deterrence, incapacitation, and rehabilitation. ${ }^{114}$

${ }^{114}$ But this view would be met with vociferous dissent by some proponents of Islamic criminal law, who would point to the proposition that the evidentiary requirements for the hudud penalties are so strict and the mitigating factors so liberal that very few people will actually be subjected to the 


\section{Superiority of Incarceration vis-à-vis the Penal Purpose of Incapacitation}

Next, it must be conceded that, concerning the penal purpose of incapacitation, incarceration is superior to judicial corporal punishment as implemented in Islamic criminal law, despite the fact that incarceration is subject to some serious flaws in this regard.

\section{a. Flaws of Incarceration}

First, while incarceration theoretically serves to meet the incapacitation policy of criminal punishment by rendering criminals unable to commit crime, crime continues to exist in prisons, even behind fortified walls guarded by trained professionals. ${ }^{115}$ Guided by sophisticated rules, ethics codes, and even constitutions, "prison gangs have considerable influence over other inmates. Their criminal activities include loan sharking, narcotics trafficking, protection, prostitution, robbery, witness intimidation, and murder." ${ }^{116}$ And, "[a]lthough guards may act like they're in charge, because of the sheer numbers, prisons are, in effect, run by prisoners. And without legal forms of settling disputes and conducting transactions, violence and criminality become the norm."117

However, this is just in reference to activities within the prison. When it comes to committing crime in the general public, prisoners are not necessarily restrained by the prison walls and, in many cases, are known to facilitate serious crime that occurs on the outside. ${ }^{118}$ Gang leaders and members, through visitors and other ingenious methods, are able to transmit messages and communication devices, currency, and contraband between prison and outside society. ${ }^{119}$

punishment and, therefore, the severity of the punishments, coupled with the mere possibility of their application, acts to sufficiently deter the proscribed conduct. Aly Aly Mansour, Hudud Crimes, in THE IsLAMIC CRIMINAL Justice SySTEM, supra note 23, at 195, 196. Dissenters would further add that "[b]y severing the hand of the robber, Islam gets to the root of evil; it extracts the rotten seeds in order to purify and protect society and the individual from destruction.” Id.

115 Dennise Orlando-Morningstar, Prison Gangs, Special NeEds OfFEnders Bull., Oct. 1997, at 1, available at http://perma.cc/X7UW-WZYY ("[P]risoners formed gangs primarily to protect themselves and to monopolize illegal prison activities such as gambling, trading contraband, narcotics trafficking, and committing contract murders.”).

${ }^{116} I d$.

${ }^{117}$ MosKos, supra note 4, at 52.

118 Orlando-Morningstar, supra note 117, at 8 (noting the example of a Florida inmate who was suspected of facilitating the murder of two Massachusetts gang members using a prison telephone and that "the true masterminds are the ones who have 24 hours to sit around in jail and figure out what to do next and to who. The men in prison are sending orders out to people on the streets").

119 See id. at 9 ("Prison gang members often rely on females (e.g., wives, mothers, sisters, and girlfriends) to relay messages, bring contraband into prison, and provide other forms of assistance.”); see also Cannabis Cat on Drugs Run Collared at Moldova Jail, BBC News (Oct. 18, 
b. Flaws of Judicial Corporal Punishment as Implemented in Islamic Criminal Law

One could argue that judicial corporal punishment as implemented in Islamic criminal law serves to incapacitate offenders to the extent that, after undergoing the ordeal, they are subject to bed rest for several days. Further, this argument could be extended to the proposition that amputation of a limb extinguishes a thief's capacity to steal or an aggressor's capacity to pose a meaningful physical threat to another. However, these arguments fail. While there are no loopholes or opportunities to exploit the physical nature of judicial corporal punishment in Islamic criminal law, the offender subjected to flagellation will recover after a few days. Thereafter, he is free to move openly throughout society and, if he chooses, to commit more crime. In the same way, the amputee-offender is not prohibited from engaging in the cerebral, logistical aspects of crime as, for example, a scam artist or as part of a larger criminal organization.

Frankly, judicial corporal punishment as implemented in Islamic criminal law only effectively achieves the penal purpose of incapacitation to the extent that it meets the penal purpose of deterrence. Put differently, the deterrent effect of the corporal punishments in Islamic criminal law may strike fear in the hearts of citizens such that the thought of committing crime becomes so fearsome that their capacity for doing so is extinguished. However, this view flies in the face of the overarching theory of civility and mercy in Islamic law. ${ }^{120}$ Thus, in regard to the penal purpose of incapacitation, "prisons get a gold star"121 despite their failure in most other respects.

\section{Superiority of Incarceration vis-à-vis the Exoneration of Wrongfully Convicted Individuals}

Next, it must be acknowledged that, despite the safeguards in the American criminal justice system in regard to evidence, due process, fundamental fairness, and standards of proof, innocent individuals are at times wrongfully convicted of crimes. ${ }^{122}$ Thus, in regard to situations where an innocent individual is wrongfully convicted and later exonerated,

2013), http://perma.cc/NZ52-BG6Y (noting the case of a cat used by inmates to deliver drugs into a prison); and Cat Caught Smuggling Cell Phones Into Russian Prison, HufF. Post (June 3, 2013), http://perma.cc/8SLH-F7XV (noting the case of a cat used to deliver a cell phone into a prison).

${ }^{120}$ Mansour, supra note 116, at 195 ("Hudud penalties are not meant to frighten Muslims but to prevent the growth of a climate favorable to the existence and spread of such crimes.”).

${ }^{121}$ Moskos, supra note 4, at 89.

122 See NAT'L REgISTRY OF EXONERATIONS, http://perma.cc/9STG-WRZS (providing detailed information on all exonerations of wrongfully convicted individuals in the United States since 1989); see also THE InNOCENCE PROJECT, http://perma.cc/Y282-YZMV (helping to exonerate wrongfully convicted individuals through the use of DNA testing). 
incarceration may be a superior form of punishment than judicial corporal punishment as implemented in Islamic criminal law. That is, if an innocent individual is wrongfully convicted and subjected to judicial corporal punishment, the complete and irreversible damage has already been inflicted if he is later exonerated of the crime. Contrarily, if an innocent individual is wrongfully convicted and sentenced to incarceration, he can simply be released from prison immediately upon his exoneration. In both cases, one would hope, the individual would be sufficiently compensated for the error.

In the most pragmatic sense, the benefits of incarceration in this regard must be couched in terms of a sliding scale, with a purely subjective tipping point. Put differently, if a wrongfully convicted individual is exonerated after spending one day of his sentence in prison, then clearly incarceration is a superior punishment to judicial corporal punishment. On the other extreme, however, if a wrongfully convicted individual is exonerated after spending twenty-five years of his sentence in prison, then many would say that judicial corporal punishment is superior to incarceration as a form of punishment. In the latter case, the individual effectively lost twenty-five years of his life for a crime that he didn't commit when, under a judicial corporal punishment regime, he could have endured a temporary, albeit excruciating ordeal then been set free to go about his life.

At which point one would be willing to undergo corporal punishment in lieu of incarceration is a purely subjective proposition; thus, there is no hard and fast line that can be drawn where, in terms of wrongful conviction, judicial corporal punishment is superior to incarceration. To put this into a practical perspective, however, consider that in 2013 there were eighty-seven wrongfully convicted individuals who were exonerated. ${ }^{123}$ The longest wrongful sentence was thirty-six years for an individual convicted in $1977 .{ }^{124}$ The shortest wrongful sentence was served by three people who were wrongfully convicted in 2013 and later exonerated within the same year. ${ }^{125}$ Assuming that they all actually went to prison, these wrongfully convicted individuals served a total of about 1,061.5 years, an average of 12.2 years per person. ${ }^{126}$ Thus, as an example, assume that an innocent person is wrongfully convicted and sentenced to twenty-five years in prison. And assume also that she knows she will be exonerated in twelve years. Would that individual rather endure an unjustified brutal corporal punishment and immediate release? Or would she rather endure twelve years of incarceration?

These are quandaries which are inherently subjective. The point, however, is that, in terms of the individual who is exonerated very shortly

123 Exonerations by Year and Type of Crime, NAT'L REGISTRY OF EXONERATIONS, http://perma.cc/9KUE-QSZP (last visited Apr. 4, 2013).

${ }^{124}$ Summary View, NAT'L REgISTRY OF EXONERATIONS, http://perma.cc/3D43-D93L (last visited Apr. 4, 2014).

${ }^{125}$ Id.

${ }^{126} I d$. 
after conviction, incarceration is clearly superior to judicial corporal punishment as implemented in Islamic criminal law. The other extreme is a matter for debate.

\section{Superiority of Incarceration vis-à-vis Excessively Dangerous Individuals}

Next, incarceration is superior to judicial corporal punishment as implemented in Islamic criminal law in regard to the treatment of certain individuals who simply pose an excessive risk of danger to society. For dangerous offenders who cannot be deterred or rehabilitated by way of judicial corporal punishment, for the safety of the community, the only prudent way of dealing with such individuals is incarceration. In this regard, recall that Islamic criminal law provides for the incarceration of such individuals until they repent and promise to reform their ways. ${ }^{127}$

\section{Inappropriateness of Judicial Corporal Punishment for Physically and Mentally Ill Persons}

Finally, it must be acknowledged that there are many classes of offenders who commit crime due to uncontrollable mental illness and, thus, cannot be deterred, incapacitated, or rehabilitated by means of judicial corporal punishment. ${ }^{128}$ Further, certain individuals who have the physical capacity to commit crime may not have the physical capacity to safely endure judicial corporal punishment as implemented in Islamic criminal law. With respect to these special offenders, recall that Islamic criminal law provides for the possibility of judicial discretion to provide a more suitable treatment for such persons ${ }^{129}$ and, accordingly, judicial corporal punishment is inappropriate for them.

B. The Penal Policy of Judicial Corporal Punishment: Lessons from Islamic Criminal Law for Curing the Ills of Incarceration as a Primary Form of Criminal Punishment

From the foregoing analysis, it is evident that judicial corporal punishment as implemented in Islamic criminal law is not without serious flaws and drawbacks and that incarceration has its clear advantages. However, the implementation of judicial corporal punishment in the United States to some degree would be superior to the status quo of mass incarceration. This section identifies the economic advantages of judicial

\footnotetext{
${ }^{127}$ See supra Part II(C)(1)(a)(iv).

${ }^{128}$ However, that is not to say that incarceration serves as a superior alternative. Further elaboration on this point, however, goes beyond the scope of this Article.

${ }^{129}$ See supra Part II(C)(1)(a)(iii).
} 
corporal punishment as implemented in Islamic criminal law and seeks to boldly confront two important questions. First, is incarceration really more compassionate than corporal judicial punishment? And second, is incarceration really as effective as judicial corporal punishment in regard to the overlapping purposes of criminal punishment?

\section{Judicial Corporal Punishment as Implemented in Islamic Criminal Law is More Effective than Incarceration}

From analyzing and probing the realities of incarceration versus judicial corporal punishment as applied in Islamic criminal law, it is evident that the results of the former are far less effective, and far more costly, than the latter vis-à-vis the aforementioned common penal aspirations of deterrence and rehabilitation. Thus, U.S. lawmakers and taxpayers should seriously consider reforming the penal system by implementing judicial corporal punishment in lieu of incarceration to some degree by observing its application in Islamic criminal law.

\section{a. Rehabilitation}

In theory, incarceration serves to meet the rehabilitative policy of criminal punishment by separating the criminal from the causes and stimuli of her misbehavior, allowing her to stop and reflect on her life free from negative influences and, thereby, reenter society as a contributing, functional member. However, observation of prison sociology shows that imprisonment only exacerbates the negative influences in a criminal's life. That is, due to the violent nature of prison life, individuals in prison often choose to associate with one of many groups or prison gangs for basic survival. ${ }^{130}$ Joining a gang requires the individual to meet and form relationships with other gang members and, often, implicitly requires a commitment to carry out orders from leadership within the prison once released. ${ }^{131}$

Thus, instead of coming out of prison reformed, rehabilitated, and ready to contribute positively to society, many inmates are released knowing that more crime is in their future. In this regard, a common punch line states that prison functions as a training institution for increasing criminal skills and that smalltime offenders enter prison for the first time inexperienced, only to

\footnotetext{
${ }^{130}$ Orlando-Morningstar, supra note 117, at 1 (noting that “[i]n correctional institutions, there is a natural tendency for inmates to form groups”).

131 See generally Marie L. Griffin \& John R. Hepburn, The Effect of Gang Affiliation on Violent Misconduct among Inmates During the Early Years of Confinement, 33 CRIM. Just. \& BEHAV. 419 (2006), available at http://perma.cc/U6QC-ZK99 (finding a positive correlation between gang affiliation and violent misconduct in prison inmates); see also Orlando-Morningstar, supra note 117, at 8 (noting that "released prison gang members are expected to remain in contact with members still in prison and to conduct gang business outside prison”).
} 
come out of prison as seasoned professional criminals. ${ }^{132}$ While authoritative sources would argue that one's individual resolve can overcome the pressure to conform to the criminality of fellow inmates, ${ }^{133}$ studies-along with the bare fact of recidivism rates - corroborate the proposition that imprisonment in general does not rehabilitate, it usually only leads to more crime. ${ }^{134}$

Perhaps the answer to curing the problem of recidivism and making prison more effective at rehabilitation, then, is to pour more tax dollars into the system to pay for intensive vocational training, basic education classes, and even undergraduate, graduate, and postgraduate degree programs. Perhaps the answer is to double, triple, or quadruple the staff to make sure that no violence ever breaks out among the inmates, that disputes between prisoners are peaceably settled, and to assist each offender in his educational, emotional, spiritual, vocational, and interpersonal rehabilitation. However decent and wise this assertion may be, however passionately one argues for it, it is, politically, a near impossibility. ${ }^{135}$ Politics do not always coincide with wisdom and decency and, since the prisoner population is not a politically sympathetic group, few politicians are willing to take up its cause. No matter how correct and prudent it may be to significantly increase expenditures into the prison system to increase its rehabilitative efficacy, the means to achieve it are simply unreachable in a democracy such as ours. Thus, a realistic, yet maximally effective, solution must be found.

Judicial corporal punishment as implemented in Islamic criminal law serves the rehabilitation purpose of criminal punishment much more effectively and at a much lower cost than incarceration. In the Islamic tradition, the family unit is the basic building block of society through which the underlying principles of Islamic society are developed and maintained; and the governmental authority very rarely intervenes in the family in a way that the family as a whole will be negatively affected. ${ }^{136}$ This, perhaps, is contrasted with the emphasis on individual freedoms and liberties as well as the role of the State in domestic disputes and the protection and education of

\footnotetext{
${ }^{132}$ Martin H. Pritikin, Is Prison Increasing Crime?, 2008 WIs. L. REV. 1049, 1055 (2008) (referring to prison as “a 'school' for criminals”), available at http://perma.cc/J9AM-N4CV.

133 See, e.g., Stanton E. Samenow, Do Prisons Really Make Offenders Worse?, Psychology TODAY (Apr. 9, 2011), http://perma.cc/2NL2-4Q23. Dr. Samenow notes that, in his conversations with inmates, it is clear that unambitious prisoners can remain neutral, work on rehabilitating themselves, and associate with like-minded inmates keen on rehabilitation and still maintain the respect of fellow inmates. Id.

${ }^{134}$ See, e.g., Edward J. Latessa \& Christopher Lowenkamp, What Works in Reducing Recidivism?, 3 U. ST. THOMAS L.J. 521, 522 (2006) (“[P]lacing low-risk offenders in with high-risk offenders may lead to an 'education' in anti-social behavior for the low-risk offender.”); see also Donald T. Hutcherson II, Crime Pays: The Connection Between Time in Prison and Future Criminal Earnings, 92 PRISON J. 315 (2012) (noting that individuals with a history of incarceration earn about $\$ 11,000$ more in illegal income than do individuals without a history of incarceration).

135 Moskos, supra note 4, at 66, 105.

${ }^{136}$ BHALA, supra note 22, at 862.
} 
children under a Western framework. ${ }^{137}$

Thus, the Islamic approach to criminal punishment naturally accounts for the wellbeing of the family and seeks to utilize the family as a primary resource for rehabilitation of the criminal. Specifically, instead of tearing the criminal away from his spouse, child(ren), and/or parents through incarceration, the family unit is kept intact for the wellbeing of the family as a whole and, on a large scale, for the overall wellbeing of society. ${ }^{138}$ Incarceration has the potential to separate children from their caregivers and role models, dependent spouses from their breadwinners, and aging parents from their offspring.

However, this principle also works in the best interest of the criminal as an individual. That is, instead of being trapped in the proximity of (and thus subject to corruption by) other criminal minds, the offender in Islamic criminal law, upon undergoing the excruciating ordeal, is immediately turned over to the care and custody of his family. ${ }^{139}$ Due to the importance of the family as a unit, Islamic law presumes that the family members are close-knit and concerned for the wellbeing of each member. ${ }^{140}$ Thus, while the criminal heals and recuperates from his wounds, he is forced to bed rest in the family home where, ideally, the members of the family unit will convene, connect, and correct the errors in the criminal's life. ${ }^{141}$

\section{b. Deterrence}

In theory, incarceration serves to meet the deterrence policy of criminal punishment by making imprisonment a severely unhappy, inconvenient, and stigmatized experience. But incontrovertible facts show that the recidivism rate in the United States is high; and, by all accounts, this rate has ostensibly remained stable. ${ }^{142}$ Indeed, studies show that roughly half of all inmates will return to prison again within three years of release, apparently undeterred by

137 Id. See also Karen J. Lugo, American Family Law and Sharia-Compliant Marriages, 13 ENGAGE, no. 2, Jul. 2012, at 79, 80, available at http://perma.cc/MQ4W-2Z86.

${ }^{138}$ Mansour, supra note 116, at 200 ("The execution of the 'bodily penalty' allows the criminal to resume his work immediately thereafter; he is also not prevented from supporting himself and his children. . . . Living with one's family keeps it intact and united. This differs from imprisonment whereby the offender is deprived of earning a living for himself and his family, which in turn may force the family into crime because of need.").

${ }^{139}$ Id. at 216 ("[Flagellation] can be readily imposed and thereby causes a minimal deprivation of liberty for the accused. He may thereafter attend to his business and serve the interest of his family. It is also in the interest of the community which thereby avoids having to take him under its responsibility as is necessary in the case of imprisonment. By the same token, the delinquent who thus escapes imprisonment is saved from being corrupted by the influence of incorrigible prisoners.”).

140 BHALA, supra note 22, at 993.

141 See Susan C. Hascall, Restorative Justice in Islam: Should Qisas be Considered a Form of Restorative Justice?, 4 BERKELEy J. MidDle E. \& IsLAMIC L. 35, 55 n.85 (2011).

142 PeW CTR. ON THE STATES, supra note 10, at 2. 
the prior experience. ${ }^{143}$ In this regard, it is important to examine the reasons why released inmates are content with returning to prison and, further, why other individuals in society are content with entering prison in the first place.

First, for some inmates, prison is the place where they feel safest. ${ }^{144}$ That is, out in society, they may be forced to reside in the path of rival gangs, murderous enemies, or simple unemployment. Trapped in the cycle of criminality, they may lack the skills to obtain lawful employment or are subject to employment discrimination based on their criminal past. ${ }^{145}$ With the economic inability to relocate and start over, they simply accept their identity as lifelong criminals, yearning for the perverse safety and camaraderie of prison partisanship, not to mention the free housing, food, and medical care. ${ }^{146}$ Thus, in this sense, prison as a taxpayer-funded refuge fails to fulfill the deterrent policy of penology.

On the other hand, judicial corporal punishment as implemented in Islamic criminal law serves the deterrence purpose of criminal punishment much more effectively and at a much lower cost than incarceration. First, the punishment of flogging is notoriously excruciating, a fact which simply cannot be obscured or twisted, thereby putting society on notice that commission of the legislated offenses can result in severe consequences. ${ }^{147}$ Second, while amputation as a punishment in Islamic criminal law is harsh and contradictory, ${ }^{148}$ it must be acknowledged that the graphic and largely unconcealable nature of this punishment squarely meets the penal policy of deterrence. Further, under Islamic criminal law, the moment when judicial

143 See supra Part I; LANGAN \& LEVIN, supra note 11 at 1; and PEW CTR. ON THE STATES, supra note 10 , at 2.

144 Orlando-Morningstar, supra note 117, at 9-10 (“[S]ome prison gang members are more comfortable in prison, with the rest of their organization, than outside prison. Consequently, it is not uncommon for released gang members to purposely violate the conditions of their supervision in order to return to prison.”).

145 See About, BAN THE Box CAMPAIGn, http://perma.cc/6PPK-3DVX (last visited Apr. 3, 2014) (describing one of several grassroots movements aimed at ending job and housing discrimination against ex-offenders).

146 See, e.g., Orin Kerr, Man Tries to Commit \$1 Robbery to Get Health Care in Prison, VoLOKH CONSPIRACY (June 21, 2011), http://perma.cc/V9CT-QNV8 (noting the case of a North Carolina man with a growth on his chest, two ruptured disks, and a problem with his left foot with no job and no medical insurance who demanded $\$ 1$ from a bank teller for the express purpose of receiving a prison sentence and, thereby, receiving the benefits of prison healthcare). But see Christopher Beam, Jailhouse Doc: What's the Health Care System Like in Prison?, SlATE (Mar. 25, 2009), http://perma.cc/7JF7-SU6X (noting that, "at best, [prison healthcare] is about as good as a lowincome health plan. At worst, it's almost nonexistent”).

147 Ahmad Abd al-Aziz al-Alfi, supra note 53, at 231 ("The deterrent function of punishment serves as a warning to the public not to commit crimes, to forbid them from imitating the criminal lest they suffer his fate.”).

${ }^{148}$ See infra Part III(A)(1). 
corporal punishment is inflicted is purely temporary. ${ }^{149}$ Immediately after the ordeal is over, the offender is turned over to her family and, thus, the punishment offers no taxpayer-funded collateral benefits in the way that incarceration does and there is no perverse incentive to commit further crime. $^{150}$

\section{Judicial Corporal Punishment is Less Costly than Incarceration}

Apart from the foregoing discussion of the superiority of judicial corporal punishment as implemented in Islamic criminal law in regard to the two penal purposes of rehabilitation and deterrence, judicial corporal punishment as implemented in Islamic criminal law is also superior to incarceration in the realm of economics. As aforementioned, annual federal expenditures on the prison system have exceeded $\$ 6.5$ billion and annual expenditures on state corrections has amounted to $\$ 52$ billion. ${ }^{151}$

One may argue that prison privatization would save precious taxpayer dollars. This view, however, fails to take into account the evils and long-term drawbacks which can result from such an arrangement. Apart from the economic incentive of high crime rates and high recidivism rates to secure the largest possible "client base," there are numerous other examples showing the ills of privatized prisons in regard to public safety, prison safety, rehabilitation of offenders, and the possibility of corruption. ${ }^{152}$

As aforementioned, judicial corporal punishment as implemented in Islamic criminal law meets the penal purposes of rehabilitation and deterrence more effectively than incarceration, and it does so at a much lower cost. First, in regard to the penal purpose of rehabilitation, the policy of

${ }^{149}$ Mansour, supra note 116, at 200 (“The hudud penalties are designed to avoid unreasonable limitations on individual freedom to the extent that they are 'bodily penalties.' They are executed for a limited duration and cause momentarily severe physical pain to the criminal and remain unforgettable to him so that in most cases, he will refrain from future criminal conduct.”).

${ }^{150} \mathrm{Id}$.

${ }^{151}$ See supra Part I.

152 See, e.g., Barry Yeoman, Privatization Would Not Benefit the Prison System, in AMERICA's PRISONS: OPPOSING VIEWPOINTS 71, $72-75$ (Roman Espejo ed., 2002) (noting the cost-cutting incentives of private prisons and how it can lead to decreased safety due to insufficient staff, defunct technology, and insufficient facilities. For example, the author cites to, inter alia, the case of inmates escaping from an old motel converted into a penitentiary, outnumbered staff members who tied up and abused juvenile offenders, and outnumbered prison guards who engaged in sexual intercourse with inmates for protection); see also Jeff Becker, Privatization Would Benefit the Prison System, in AMERICA's PRISONS, supra, at 66, 67 (noting the case of six inmates who escaped from a private prison by cutting a hole through the fence); and KARYL KICENSKI, CASHING IN ON CRIME: THE DRIVE to Privatize CALIFORnia State Prisons 1 (2014) (noting the case of a Pennsylvania judge who was convicted for having accepted approximately \$2.6 million in kickbacks from a private prison facility in exchange for rulings sentencing juveniles to the facility); see also generally, K.C. CARCERAl, Prison, Inc.: A Convict EXPOSEs LIFE Inside A PRIVATE Prison 219 (2006) (noting the "cost control" incentives for private prisons and their numerous ill effects). 
judicial corporal punishment as implemented in Islamic criminal law seeks to shift the cost away from the taxpayers and onto the families of offenders. ${ }^{153}$ That is, instead of extracting dollars out of the taxpayer's pocket for vocational training programs, educational classes, counseling, and religious resources for the betterment of the criminal, the family of the criminal becomes responsible for providing these resources. And, as to the penal purpose of deterrence, the taxpayer cost of administering justice via judicial corporal punishment as implemented in Islamic criminal law is essentially limited to the price of the weapon and the wage of the punisher. ${ }^{154}$

\section{Judicial Corporal Punishment as Implemented in Islamic Criminal Law is More Compassionate than Incarceration}

As mentioned above, the status quo of incarceration in the United States likely came about as a compassionate or remorseful response to the inequality, racism, and fundamental evil which corporal punishment seemed to represent in a most graphic way. ${ }^{155}$ And, to be sure, the infliction of corporal punishment is a strikingly graphic and brutal ordeal. However, the status quo of incarceration has not eliminated the threat of experiencing brutality and violence for imprisoned offenders.

Indeed, in some cases, the experience of incarcerated life is more brutal, more violent, and more inhumane than the ordeal of judicial corporal punishment under Islamic criminal law. Thus, in regard to the idea of compassion for the bodily integrity of offenders subjected to the status quo of incarceration, judicial corporal punishment under Islamic criminal law is more compassionate. Finally, judicial corporal punishment under Islamic criminal law is more humane than the status quo of incarceration in regard to the collateral damage that is inflicted upon an offender's friends, family, and community when he is separated from society and locked up.

\section{a. Inhumanity of Incarcerated Life}

Perhaps the most poignant argument militating against judicial corporal punishment is the repugnancy of the idea of the state taking an affirmative

\footnotetext{
153 See supra Part III(A)(1)(a).

${ }^{154}$ With today's medical and scientific advancements, however, it should be acknowledged that taxpayers must bear a certain degree of costs for the administration of justice in Islamic criminal law. The facilities and personnel for administering judicial corporal punishment must be obtained with the utmost regard for the medical safety of the criminal and fundamental compassion. For example, a jurisdiction administering judicial corporal punishment would have to provide medically sanitary facilities for the ordeal. And, at every administration of judicial corporal punishment, there would have to be a qualified medical staff on site to inform the criminal of the process, instruct the punisher on the correct and lawful technique, and to ensure that there is emergency medical support available if necessary.

155 See supra Part II(C)(2)(a)(iv).
} 
act to inflict pain on and violate the bodily integrity of a human being. Indeed, such a proposition is repugnant and difficult to stomach. However, crime is an unfortunate reality in society that must be addressed; offenders must be deterred from their wrongdoing and, if possible, rehabilitated in order to rejoin the community as a functioning member.

The status quo of incarceration is largely premised on this fear against the state taking an affirmative action violating the individual autonomy and integrity of one's person. ${ }^{156}$ Thus, instead of taking the affirmative act of inflicting corporal punishment on offenders, the state opts for taking the negative, less controversial act of incarcerating them. ${ }^{157}$ However, without substantial resources to make incarcerated life more civilized, less violent, and more amenable to rehabilitation (which, as previously discussed, is politically implausible in the United States) ${ }^{158}$, the negative act of incarceration only serves to sweep the brutal reality of criminal punishment into the yards, cells, and showers of prison, obscured behind fortified walls and largely free of outside attention from the media and members of the public. Incarceration is not necessarily more humane than judicial corporal punishment.

Apart from self-harm, there are essentially two sources of violence to which an inmate may be subjected: prison guards and fellow inmates. First, one need only mention the notorious examples of the Stanford Prison

\footnotetext{
156 MURTAGH, supra note 113, at 66. This fear is a byproduct of classic American ideals of individual liberty and bodily autonomy and integrity, encapsulated in some of the most basic principles of our Constitutional and criminal jurisprudence. See, e.g., Skinner v. Oklahoma, 316 U.S. 535 (1942) (finding that procreation is a fundamental right under the Constitution and that a state statute allowing the state to sterilize offenders convicted three or more times of "felonies involving moral turpitude" was unconstitutional under the Equal Protection Clause of the Fourteenth Amendment since some felonies of equal offense were specifically excluded from the act) (Stone, CJ., concurring); see also, e.g., Griswold v. Connecticut, 381 U.S. 479 (1965) (finding that the "emanations" from the First, Third, Fourth, Fifth, and Ninth Amendments create "penumbral rights of 'privacy and repose"” and that a state statute forbidding the counseling of married couples in contraception methods was an unconstitutional violation of a right to privacy) (Black \& Stewart, JJ., dissenting); but see, Buck v. Bell, 274 U.S. 200 (1927) (finding that a state statute allowing the sterilization of mentally retarded persons committed to the state mental institution after a hearing did not violate the Due Process and Equal Protection Clauses of the Fourteenth Amendment) (Butler, J., dissenting).

157 MuRTAGH, supra note 113, at 66.

${ }^{158}$ See supra Part III(B)(1)(a).
} 
Experiment ${ }^{159}$ or, perhaps, the Abu Ghraib prison scandal ${ }^{160}$ to recognize the capacity of otherwise normal human beings to commit atrocious acts from a position of power. Nonetheless, despite the capacity for abuse, the use of guards is better than the alternative of leaving the prisoners to govern themselves. ${ }^{161}$ Unfortunately, the latter scenario is often the de facto case. ${ }^{162}$

Second, inmates are faced with the possibility of violence from other inmates in a largely lawless setting from which escape is impossible. ${ }^{163}$ While doubt exists as to the veracity of the portrayal of prison life in popular culture through television, movies, and other forms of media, academia confirms that incarceration involves a substantial risk of being subjected to severe violence, semi-consensual and non-consensual sexual contact, and even death. ${ }^{164}$ In reality, though, no rational person can predict the kinds of repugnant acts that can occur within the cells and buildings that contain some of society's most

159 The Stanford Prison Experiment was conducted by Stanford University psychology professor Philip Zimbardo in 1971. Kathleen O'Toole, The Stanford Prison Experiment: Still Powerful after All These Years, StANFORD News Service (Jan. 8, 1997) http://perma.cc/L7S4-BHNJ. The experiment involved a makeshift prison on campus and twenty-four student-subjects, chosen as the "most normal” out of a group of seventy-five candidates. Id. Some were assigned to be guards and the rest were assigned as prisoners. Id. Those assigned to be guards were "instructed that they were not to use violence but that their job was to maintain control of the prison.” Id. The experiment rapidly turned into a situation of horrific abuse carried out by the guards against the prisoners and, at the encouragement of the guards, the prisoners even abused each other. Id. For example, the guards forced the prisoners to undergo protracted exercise routines, removed their mattresses for bad behavior, only allowed them to use a bucket for excrement and forbade them from emptying it, and forced the prisoners to undergo other dehumanizing and degrading acts. Id. Although the experiment was to last between seven and fourteen days, it had to be prematurely stopped on the sixth day due to the behavior of the subjects. Id.

${ }^{160}$ Between 2003 and 2004, U.S. Army personnel stationed at Abu Ghraib prison in Iraq committed several serious human rights abuses against detainees following the fall of Saddam Hussein and the subsequent war in Iraq. Seymour M. Hersh, Torture at Abu Ghraib, NEw YoRKER (May 10, 2004), http://perma.cc/A6EV-JDEW. The misbehavior included physical and sexual abuse, torture, rape, and even resulted in the deaths of some detainees. Id. Experts have drawn stunning comparisons between the Stanford Prison Experiment and the Abu Ghraib scandal. See generally George R. Mastroiann \& George Reed, Apples, Barrels, and Abu Ghraib, 39 SociologiCAL Focus 239 (2006).

161 CARCERAL, supra note 154, at 220-221.

162 Moskos, supra note 4, at 52 ("Although guards may act like they're in charge, because of the sheer numbers, prisons are, in effect, run by prisoners. And without legal forms of settling disputes and conducting transactions, violence and criminality become the norm.”).

${ }^{163}$ As aforementioned, while incarceration is the best method for incapacitating offenders (short of capital punishment), criminal behavior and misconduct is rampant within the prison walls; see supra Part III(A)(2).

164 See generally Rebecca Trammell, Enforcing the Convict Code: Violence AND PRison CULTURE 19 (2012) (noting that interviewees in a study asserted that the portrayal of prison life in popular culture is misleading, but that ample data indicating an abundance of violence in prison refutes such assertions); see also MATTHEW SiLBERMAN, A WORLD of ViOLENCE: CORRECTIONS IN AMERICA 16 (1995) (“[I]n one way or another, survival in prison depends on adapting to violence as either perpetrator or victim.”). 
dangerous minds.

In contrast to the status quo of incarceration, judicial corporal punishment as implemented in Islamic criminal law can be surprisingly more compassionate. First, the certitude and finite nature of judicial corporal punishment as implemented in Islamic criminal law is superior to the horrific insecurity and perpetual uncertainty which prevails in the status quo of incarceration. That is, a criminal offender sentenced to incarceration, in reality, is not aware of what his experience in prison will be like. To be sure, there are some well-run prisons and, further, the nature of the offender, his interpersonal skills, and his personal inclination toward aggression plays a role, but statistically he is very likely to be involved in some degree of violence during his sentence, which may even exceed the level of violence which is meted out as corporal punishment in Islamic criminal law. ${ }^{165}$ Further, due to the possibility of administrative complications and good-faith errors, he may not be certain of his safety or timely release upon the culmination of his sentence. ${ }^{166}$

In contrast to this reality, the sentencing of judicial corporal punishment as implemented in Islamic criminal law is, without exception, absolutely precise. The offender knows exactly the punishment he is to receive and, when it is over, he knows his sentence has been forever satisfied. Further, judicial corporal punishment as applied in Islamic criminal law is more humane than incarceration in the sense that, following infliction of the punishment, the criminal is to be immediately turned over to the custody of her family who, in the Islamic tradition, cares most for her wellbeing. The family of the criminal is meant to nurture her, help correct her criminal proclivities, and, ultimately, rehabilitate her into society. The prison community under the status quo of incarceration, in general, does not fulfill any similar positive role.

\footnotetext{
165 See generally Silberman, supra note 166 (noting the author's research of correctional issues in a maximum security prison over a fourteen-month period, which included several instances of violence). Silberman specifically notes the occurrence of eight homicides in a twenty-six-month period in the prison and describes their causes as anything from racial affiliation to sexual orientation to "snitching." Id. at 24-25, 33-34.

166 See, e.g., Complaint and Jury Demand, Ankeney v. Colorado, 1:14-cv-00007-BNB (D. Colo. Jan. 2, 2014).

Ankeny is a class action lawsuit alleging that the Colorado Department of Corrections has failed to correctly account for the time served of several inmates, including factors which could lawfully mitigate the amount of time required, thus causing inmates to serve more time than they should. Id.; see also, Kirk Mitchell, Lawsuit Says Sentences for Thousands of Colorado Inmates Are Too Long, DeNVER PosT, Jan. 2, 2014, http://perma.cc/7ZRV-CA8G; and Jill Disis, Woman Accidentally is Put into Male Cellblock at Marion County Jail, InDPLS STAR, Mar. 26, 2014, http://perma.cc/U7FCK7LE (noting an administrative error which caused a female inmate to be put into a cell with nine other men for an unknown amount of time).
} 


\section{b. Collateral Damage of Incarceration}

Finally, it is important to acknowledge the severe collateral damage that results when an individual undergoes incarceration. Often, incarceration results in the harm or total decimation of a familial, marital, or communal relationship. That is, when a spouse is incarcerated, someone is torn from a marital partner, a source of support, and perhaps the sole breadwinner. When a parent is incarcerated, a child may lose a caregiver and role model. When a contributor to society is incarcerated, a community loses a participant and an employer may lose an employee. All the while, those remaining on the outside are left to survive without the incarcerated individual. Family members who previously relied on the individual may be left to stagnate, eventually becoming a burden on fellow taxpayers and even, perhaps, new participants in the machine of criminality.

To be sure, there are some criminal offenders who ought to be separated from their families, spouses, children, and/or the whole community for purposes of safety. However, deprivation of liberty via incarceration is only utilized in Islamic criminal law to the extent that the offender is shown to be incorrigible and unremorseful. ${ }^{167}$ In all other cases, judicial corporal punishment as implemented in Islamic criminal law is applied with an eye toward the overall wellbeing of the offender, his family, and his community. ${ }^{168}$ After infliction of the punishment, he is permitted to move freely about society, continue living with his family, and work to support himself and his household. ${ }^{169}$ Thus, judicial corporal punishment as implemented in Islamic criminal law is more compassionate than the status quo of incarceration to the extent that collateral harm to the spouse, children, and community of the offender is minimized and the family unit is kept intact if possible.

\section{PART IV: CONCLUSION AND PRACTICAL CONSIDERATIONS}

In conclusion, the purpose of this Article was to detail judicial corporal punishment as a superior alternative to the status quo of incarceration in the United States by pointing to the example of Islamic criminal law. Thus, this Article was narrowly tailored to the question at hand and did not address two important issues that are outside of its scope. First, the Article did not claim that judicial corporal punishment as implemented in Islamic criminal law is

167 Benmelha, supra note 54, at 217 (“[Incarceration] is usually reserved for incorrigible criminals and those who are deemed to be dangerous recidivists.”).

${ }^{168}$ Mansour, supra note 116, at 200 (“[T]he execution of the 'bodily penalty' allows the criminal to resume his work immediately thereafter; he is also not prevented from supporting himself and his children. . . . Living with one's family keeps it intact and united. . . . The absence of the head of the family may lead the other members of the family into delinquent and criminal behavior.”).

${ }^{169} I d$. 
the supreme answer to ridding the world of crime, rehabilitating offenders, and making the criminal justice system fairer. Rather, it argues that judicial corporal punishment as implemented in Islamic criminal law is superior to the status quo of mass incarceration, despite the drawbacks of judicial corporal punishment. Second, the Article did not attempt to provide a detailed framework through which judicial corporal punishment could be introduced practically into the U.S. criminal justice system. ${ }^{170}$

\footnotetext{
${ }^{170}$ A few concepts, however, can be noted regarding the latter point. Professor Peter Moskos argues for the implementation of judicial corporal punishment in the United States based largely on the Singaporean and Malaysian models. Moskos, supra note 4, at 10. In doing so, Moskos notes first that flogging should never occur without the consent of the offender. Id. at 144. That is, if the convicted offender wishes to avoid corporal punishment and simply serve the standard prison sentence for his offense, then nothing should stop him from making that decision. Second, Moskos argues for a formula of two lashes substituted for each year that would be served in prison, with a minimum of one lash for shorter sentences and a maximum of thirty lashes. Id. In all cases, though, the advice of a doctor would always be taken into consideration. Id. at 145.
} 